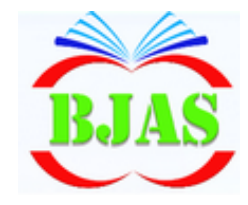

ISSN $1814-5868$
Available online at http://bajas.edu.iq

https://doi.org/10.37077/25200860.2020.33.1.11

College of Agriculture, University of Basrah

Basrah J. Agric. Sci., 33(1): 135-158, 2020
Basrah Journal

of Agricultural

Sciences

E-ISSN: 2520-0860

\title{
Effect of Electrical Stimulation on Qualitative Characteristics of Aged Chicken Carcasses: A Comprehensive Review
}

\begin{abstract}
Asaad R. Al-Hilphy ${ }^{1 *}$, Majid H. Al-Asadi², Noora K. Al-Hmedawy ${ }^{2}$, Hong Zhuang ${ }^{3}$
${ }^{1}$ Department of Food Science, College of Agriculture, University of Basrah, Iraq. ${ }^{2}$ Department of Animal Production, College of Agriculture, University of Basrah, Iraq. ${ }^{3}$ Quality and Safety Assessment Research Unit, U.S. National Poultry Research Center, Agricultural Research Service, U.S. Department of Agriculture, 950 College Station Road, Athens, GA 30605-2720, USA
\end{abstract}

*Corresponding author e-mail: aalhilphy@ yahoo.co.uk

Received 8 March 2020; Accepted 23 April 2020; Available online 27 June 2020

\begin{abstract}
The aim of this review was to summarize the histological, physical, chemical and microbial aspects and ways to stop the fluctuation in meat quality in addition to enhance its sensory quality using electrical stimulation. The low-voltage electrical stimulation and high-voltage electrical stimulation were employed. Electrical stimulation improves quality of poultry meat by reducing shear, increasing Sarcomere length, and reducing the diameter of muscle fibers. Low-voltage electrical stimulation affects voltages (120 volts directly in the nervous system, while high voltages were more than enough) to remove the polarization of the cover and produce a dense physio-chemical response in the muscles that had a direct effect. Electrical stimulation and injection with salts of sodium chloride and calcium chloride in the carcasses of female goats improved the tenderness of the meat. It was found that electrical stimulation accelerated the development of rigor mortis. Although electrical stimulation reduces breast meat shear, there was limited information about the effects of electrical stimulation on the other quality attributes of poultry meat and the results vary with quality attribute and differ from experimental conditions High voltage (higher than 120 volts) electrical stimulation improved meat quality and decreased the $\mathrm{pH}$. Low voltages (below 120 volts) are used to ensure the safety of workers and give the desired results when used in commercial applications.
\end{abstract}

Keywords: Electrical stimulation, Physical, Chemical, Microbial characteristics, Meat tenderness.

\section{Introduction}

There are approximately 250 million of chickens worldwide, and about 85 millions of adult chickens marketed annually, including the laying hens that have finished their productive year (e.g. at age of 1.5 years), and the birds from the foundation flocks, and parent flocks that are used in the processes of breeding (Al-Fayyadh et al., 2011).

The adult chickens are characterized by the quality of hard meat, dry and low-trough. 
These characteristics are considered one of the most important factors for palatability to the consumer and one of the first factors felt by humans when eating and cutting meat in the mouth into small pieces. It reflects how easy to cut meat into small segments and how easy that teeth penetrate a piece of meat when chewing. Also, this characteristic is affected by the degree of adhesion or connectivity between the muscle fibres with each other, or in other words strength of bonding tissues that surround the muscle fibres and bundles. The meat tenderness relates to the amount of connective tissues in the muscles and the degree of union of muscle proteins with water and the nature of muscle proteins. Besides, it depends on the amount of fat available at muscles (Jassim et al., 2011; Agbeniga, 2018).

After slaughtering the animal and interruption of breath, pyruvic acid changes to lactic acid, which accumulation in muscles leads to reduce the value of $\mathrm{pH}$, and there is not a sufficient amount of ATP released for expanding muscles leading to shrinking and spam of muscles. Therefore, it's preferable to ageing meat after 24 hours following slaughtering in chickens and ducks. This process is expensive for the plant. When the process of ageing is quick from 0-2 hours following slaughtering, $50-80 \%$ of meat is stiff. However, when ageing at 6 hours following slaughtering, 70-80\% of chicken meat was tender (Asghar \& Pearson, 1980; Mota -Rojas et al., 2012).

One of the methods currently used to reduce the ageing time was the electrical stimulation after slaughtering for speeding rigor mortis, so that muscles can be matured within two hours instead of six or more, thus reducing the costs of processing, cooling, storage and energy discharged by the factory
(Warriss, 2000). Electrical stimulation has been studied as a means of reducing aging time and has currently been used commercially. Electrical stimulation is one of the novel methods that use to tenderize meat (Bhat et al., 2019).

Electrical stimulation improves the meat tenderness through decreasing cut values and increasing the length of sarcomere and lowering diameter of muscle fibres. Moreover, there is a possibility of flanging meat at less than two hours of slaughtering at tenderness equivalent to tenderness of flanged and aged meat for four hours after slaughtering. Therefore, electrical stimulation decreases storage time to $50 \%$ or more and leads to lowering storing cost. Electrical stimulation leads to fast removing of feathers as well as the stimulation facilitates reducing microbial load on poultry (Thompson et al., 1987; Adeyemi \& Sazili, 2014). Different trends in the meat industry are factors that have contributed significantly to improving or maintaining the quality of products. Recently, the meat industry is in line with the consumer's needs for meat with health, safety, and nutritional values and good appearance. Therefore, the aim of this review is to assess the histological, physical, chemical and microbial properties and ways to stop the fluctuation in meat quality and enhance its sensory properties using electrical stimulation.

\section{An Overview of Electrical Stimulation}

Electrical Stimulation is the process of applying electrical voltage through a bird body directly after slaughtering and bleeding, resulting in a response in the nervous and muscular systems to voltages or amperes and leading to the occurrence of physiological or biological changes to the meat (Li et al., 1993). The first man who used electrical 
stimulation is the scientist named Benjamin Franklin who has worked on turkeys, dating back to 1947, and the meat has been tenderized. The mechanism responsible for the improvement of meat tenderness by electrical stimulation is due to the fact that the electrical stimulation reduces the phenomenon of short cooling since the probability of occurrence is greater when $\mathrm{Ca}+2$ ions are released and ATP level stays high in muscles (Asghar \& Pearson, 1980).

Low $\mathrm{pH}$ and high heat in the muscles immediately after slaughter tear off the membranes of the lysosomes, liberating the lysosomal enzymes to the cytoplasm. This impact can be caused by electrical stimulation that leads to a fast decrease in $\mathrm{pH}$ while the slaughtered bird's temperature is high (Asghar \& Pearson, 1980). Also, a physical disruption in muscle fibres (Birkhold et al., 1992; Birkhold \& Sams, 1993, 1995).

\section{Benefits of Electrical Stimulation}

There are several benefits of electric stimulation of slaughtered birds are improve the tenderness of meat through decreasing values of cut ( $\mathrm{Li}$ et al., 1994a; Hirshler \& Sams, 1998), increasing the length of the sarcomere (Birkhold \& Sams, 1993), reducing the diameter of muscle fibre (Kannan et al., 1991), and the possibility of flanging meat within less than two hours following slaughtering and with tenderness equivalent flanged and aged meat for four hours following slaughtering (Owens \& Sams, 1998; Zocchi \& Sams, 1999), then reducing time required for storage to $50 \%$ or more storage which leads to reduce the cost of storage. Low microbial load available on slaughtered birds could reduce efforts necessary to remove feathers.

\section{Mechanism of Electrical Stimulation}

The use of electrical stimulation on the slaughtered bird and the flow of electric current cause severe contraction in muscles. It was similar to what happens in the living muscle when shrinking with the difference that the flowing current is very large in the case of electrical stimulation compared with those supplied through the nervous system during the life of the animal. The stimulus (the force of action) moves from the surface of the axon to the neuron fibre through synapses and reaches surface of the neuromuscular connectives or what's called neuromuscular connectivity. When a stimulus arrives at an end plate causes a release of Acetyl Choline (ACH) of small vesicles found in the branches of end nerves through Synapses, and ACH is in contact with the $\mathrm{ACH}$ membrane, therefore the sodium ion permeability changes as the Sarcolemma cover becomes more permeable to the sodium ions, and then there will be a change in electric voltage from negative into positive inside the cell membrane. This stimulus is transferred to (tubule L) system, nearby (Zline) and then the effect reaches the longitudinal tubes (L-system) in the sarcoplasmic system. As a result, the associated calcium ions are released and the concentration of free calcium ions increases from 10-7 mole to 10-5 mole, which spread through via vacuum among muscular fibres. The process of contraction commences by using electrical stimulation. Electrical stimulation is not allowed to delay because the amount of change in $\mathrm{pH}$ during a certain period decreases. The temperature of the slaughtered bird begins to decline after bleeding and all these causes affect the rate of glycolysis in muscle (Asghar et al., 1983; Polidori \& Vincenzetti, 2017; Agbeniga, 2018). Therefore, it should be carried out early, such as 15-20 minutes following after 
slaughtering, because the nervous system and nerves remain effective during this period. This observation is important in the case of the use of low-voltage stimulation as it works through its effect on the nervous system directly. While high-voltage stimulation, which was more than $200 \mathrm{~V}$, gives intense current enough to remove the polarization of the cover and produces a physiochemical response affecting muscles directly (Warriss, 2000).

\section{Electrical Stimulation Systems}

There are many electrical stimulation systems used in the poultry industry, which are classified mainly into two basic systems :

A-Low voltage electrical stimulation (Fehrman et al., 2019).

B-High voltage electrical stimulation (Mombeni et al., 2013; López-Campos et al., 2018).

\section{High voltage electrical stimulation}

In this system, voltages higher than 120 volts are used, which is considered common compared with the other systems. Maki \& Froning (1987) referred to the fact that the stimulation by using $(800 \mathrm{~V}, \mathrm{AC}, 340$ milliAmpere, $4 \mathrm{~s}$ ON, $5 \mathrm{~s}$ OFF, for 36 seconds) led to a significant decrease in the value of $\mathrm{pH}$ for thigh muscles after 15 minutes of slaughtering, and cut values of the chest muscles fallen compared with chest muscles resulting from slaughtered birds without electrical stimulation. Mombeni et al. (2013) stated that the use of high voltage electrical stimulation was success to decrease the $\mathrm{pH}$ of meat and concluded that high voltage electrical stimulation improved meat quality. Thompson et al. (1987) indicated that the high voltage was led to an improvement in the tenderness of flanged cuts directly after slaughtering.

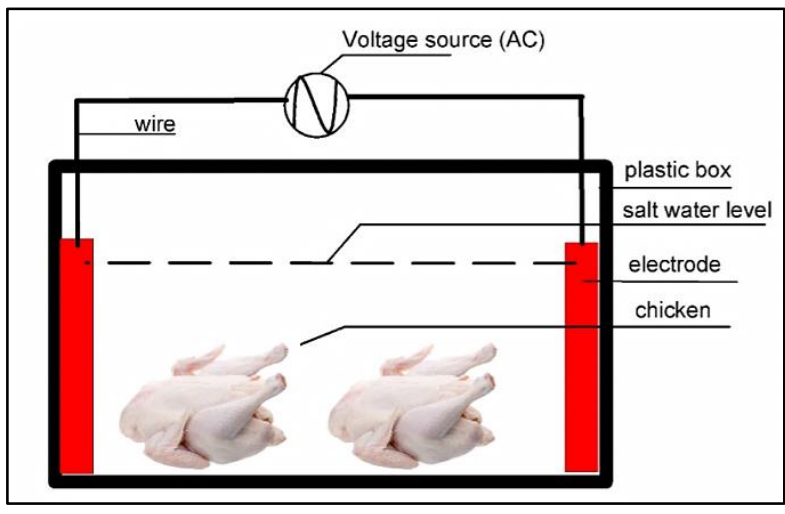

Kannan et al. (1991) worked on stimulating slaughtered chickens electrically (220 and 330 V, 4 s, 6 s ON: OFF, for $110 \mathrm{~s}$ ) at the age of 60 weeks. Researchers found that there's no impact of electrical stimulation on the $\mathrm{pH}$ after passing $24 \mathrm{~h}$ from slaughtering or length of Sarcomere. However, the diameter of fibres decreased after $24 \mathrm{~h}$ from slaughtering from 71.11 to 63.05 micron, and from 66.66 to 59.17 micron in the muscle electrically stimulated with a voltage of 220 and $330 \mathrm{~V}$, respectively.

Hirshler \& Sams (1998) pointed out that electrically stimulating chickens with an electric current amounting to 450 milliamp caused reduction in the cutting values by 50\% when measured Lyon (1991)methods. The results of these two devices were consistent with sensory evaluation results. Zocchi \& Sams (1999) noticed that muscles of a flanged broiler, following two hours of slaughtering and resulting from slaughtered birds electrically stimulated (450 volts, 450 milliamper, $2 \mathrm{~s}$ ON, 1s OFF, 5 pulses) had the same values of cuts of flanged muscles after four hours of slaughtering which resulted from slaughtered chickens not electrically stimulated (Sams, 1995).

Alvarado \& Sams (2000) brought to light that electrical stimulation $(370 \mathrm{~V}$ for broiler meat, $580 \mathrm{~mA}$ for ducks, $60 \mathrm{~Hz}, 2 \mathrm{~s} \mathrm{ON}, 1 \mathrm{~s}$ OFF, 5 pulses) led to a significant reduction in the $\mathrm{pH}$ of the muscles an hour after 
slaughter and an increase in the cut-off values after $1.25 \mathrm{~h}$ of slaughter.

\section{Low voltage electrical stimulation}

In this system, voltages below 120 volts are used to ensure the safety of workers. There's a tendency towards this system if low voltages give the desired results when used in commercial applications (Eikelenboom et al., 1985). Froning \& Uijttenboogaart (1988) made it clear that stimulation of broiler meat $(100 \mathrm{~V}, 1 \mathrm{~s} \mathrm{ON}, 0.5 \mathrm{~s}$ OFF, for $90 \mathrm{sec})$ did not improve the tenderness of flanged muscles after removing internal guts, or following 15 minutes after that. On the other hand, the electrical stimulation resulted in a significant improvement in the elasticity of the flanged muscles after two or four hours of removing internal guts. Stimulation of electrically slaughtered boiler meat with a voltage of 50 didn't improved tenderness of flanged muscles when cuts values as well as values of tenderness and juiciness were measured (Lyon et al., 1989).

Gault et al. (2000) came to point that stimulation of electrically slaughtered boiler meat with a low voltage (100) decreased the $\mathrm{pH}$ for chest muscles with an amount of 0.5 units following 20 minutes of slaughter, whether $\mathrm{pH}$ was measured by using Iodoacetate or direct connection of an electrode to the muscle .

\section{Salts Used in Electrical Stimulation}

Salts alone have been used extensively in softening poultry meat, especially laying hens. On this basis, a number of researchers had studied the effect of using electrical stimulation and salts together. Young \& Lyon (1997) disclosed that electrical stimulation (450 mAbird $^{-1}, 2$ s ON, 1 s OFF, 5 pulses) resulted in the fall of $\mathrm{pH}$ of meat treated with sodium chloride.
Hirschler \& Sams (1998) found that it is possible to obtain flanged meat after two hours of slaughter and with a tenderness equivalent to the tenderness of the flanged and aged meat through using the two techniques; electrical stimulation (450 mA. bird $^{-1}, 7$ pulses, 2 s ON, 1 s OFF) and an injection using $10 \%$ of ( $3 \% \mathrm{STPP})$ together.

The researchers found that the application of these two treatments together gave meat tenderness higher than that of electrically stimulated meat only, and the results of measuring the method were similar when measured with cutting devices or sensory evaluation. Young et al. (1999) studied the effect of using electrical stimulation $(200 \mathrm{~V}$, 115-125 mA, 1s OFF: 2s ON, AC, for one minute) with triple sodium phosphate salts (4\% STPP) on changes in the quality of chest meat in broilers after cooling, they noted that the use of these techniques combined gave more tender meat immediately after cooling compared to electrically stimulated meat or treated with salt separately or electrically nonstimulated and non-salt treatment (control). The cut values for these treatments were 4.44, $5.88, \quad 8.15$ and $6.02 \mathrm{~kg}$, respectively. Tenderness of meat after 2, 4 and 6 hours of cooling was not significantly different in all treatments from the control treatment.

Young \& Buhr (2000) used sodium chloride salts with or without polyphosphate triple sodium salts (4\% STPP) in a possibility to enhance the effect of electrical stimulation (200 V, 115-125 mA.bird ${ }^{-1}$, AC, 2 s ON: $1 \mathrm{~s}$ OFF). The researchers observed that only the cuts treated by electrical stimulation, and treated with sodium chloride salts separately gave less liquid loss compared to the electrically motivated cuts and treated with both sodium chloride and STPP salts.

\section{Histological characteristics}


Effect of electrical stimulation on the length of sarcomere

Fibroblasts are synthetic tissue proteins consisting of strands that are responsible for directly diminishing and extending the muscle cells, these proteins include actin, myosin, and tropomyosin, and troponin protein of types T, C, I, Actinin: $\beta, \alpha$, protein (M-line) of all types: M-protein, Myomesin and Creatin Kinase), C-protein and Desmin. The most proteins that suffers decomposition and breakdown are seven types including tannin, desmin, paranemin napolin, synemin, filamin and $\mathrm{T}$ - troponin. These proteins are classified as clico-proteins and have a significant role in the synthesis of sarcomere and considered basic materials for kalpin enzyme (Robson et al., 1997). There is an association between actin and mycin and increase thickness of the muscle fibres leads to reduce of tenderness (Taylor et al., 1995).

Electrical stimulation has the effect of increasing the length of the sarcomere. One possible reason for increasing the length of the sarcomere as a result of the stimulation may be the breakage of the accidental bridges, or shortage of energy components in the muscle and allow it to shrink (Owens \& Sams, 1997).

As for the muscle type, the sarcomere in the white muscle fibres is shorter than the sarcomere of the red muscle fibres that they reached 1.85 and 2.00 micron respectively. These variations are attributed to nature, type and diameter of prevailing fibresin each type of muscles (Haj-Saeed, 2004).

Al-Rubaiya et al. (2006) showed that the length of sarcomere was due to high voltage electrical stimulation. There is no difference in the length of sarcomere due to the increase of the stimulation time within one voltage. In another study, Apparao et al. (2009) observed a significant effect in increasing sarcomere length when treated with only $220 \mathrm{~V}$ at storage time of $1 \mathrm{~h}$ after electrical stimulation). There was no significant difference between the control treatment and the second treatment $110 \mathrm{~V}$ for both times (1 and $24 \mathrm{~h}$ ).

Al-Hmedawy (2019) disclosed that the length of sarcomere had been affected significantly $(p<0.05)$ by the electric stimulation where length of sarcomere was decreased from 1.89-1.87 when electrical field strength increased from 3.67-7.33 V.cm

1 . The results showed the length of sarcomere at an intensity of the electrical field 7.33 V.cm ${ }^{-1}(220 \mathrm{~V})$ in chicken as time progresses .

\section{Effect of electrical stimulation on muscle fibre diameter}

Kannan et al. (1991) studied the effect of electrical stimulation on diameter of muscle fibres, where he found a fall in the diameter of muscle fibres for laying hens electrically stimulated with a voltage of 220 or $330 \mathrm{~V}$. In a study carried out by Naveena \& Mendiratta (2001) on boiler meat of aged chickens raised 52 weeks, there's no effect on the diameter of muscle fibres caused by electrical stimulation.

\section{Effect of electrical stimulation on MFI}

There the effect of electrical stimulation on muscle fibres breakage through its effect on breaking down the structural composition of muscle and on rupture and breakdown in the Z-line (Hopkins \& Thompson, 2001). Apparao et al. (2009) came to a point that there was a significant fall $(\mathrm{p}<0.01)$ in the manual of muscle fibres' breakage compared with the control treatment, but there was not a significant effect between a control treatment and the second treatment at $110 \mathrm{~V}$.

Al-Hmedawy (2019) stated that the manual of muscle fibres' breakage was significantly affected $(p \leq 0.05)$ by electrical stimulation. 
The results showed an increased evidence of muscle fibres breakage when the electric field intensity $7.33 \mathrm{~V} . \mathrm{cm}^{-1}(220 \mathrm{~V})$ in chickens at time progressing, and slowness reflected a significant difference from chickens in the manual of muscle fibres' breakage. AlRubaiya et al. (2010) stated that the use of electrical stimulation and injection with salts of sodium chloride and calcium chloride in the carcasses of female goats improved the tendency of the meat .

\section{Effect of Electrical Stimulation on pH}

The $\mathrm{pH}$ had an effect toward the physical properties of meat. One of these effects are dark or light colour. High pH values (5.8 and above) increase the water load capacity, showing a darker colour and stiff construction and providing suitable conditions for rot. Low $\mathrm{pH}$ value (5.5 or less) leads to different changes from the high $\mathrm{pH}$ value, such as showing transparent colour and smooth muscle structure with an increase in the length of storage period (Taher, 1990). The $\mathrm{pH}$ values of the stored meat are affected by the conversion of glycogen to lactic acid. Whenever there was an increase in conversion process, $\mathrm{pH}$ decreases and then storage life of meat increases. The range of $\mathrm{pH}$ fall after slaughtering and occurrence of rigor mortis have a significant role in some sensory characteristics (such as tenderness) and enzymatic degradation (Lawrie, 1958). The fall in $\mathrm{pH}$ values might be affected by physiological status of a bird before slaughtering, which in turn affects nature of interactions after slaughtering. This means that there is a relationship between the efficacy of the bird's body before and after slaughter, and the relationship is direct between the effectiveness of muscles after slaughter and the quality and traits of meat produced (Davey \& Winger, 1988).
Offer (1991) studied the rise of $\mathrm{pH}$ value a one degree from normal limits leads to denaturation of protein 12 times.

A study conducted by Khan \& Nakamura (1970) noted the low $\mathrm{pH}$ due to an increase in the stimulation time within one voltage. It was shown by the $\mathrm{pH}$ values that the electrical stimulation accelerated the development of rigor mortis by lowering the $\mathrm{pH}$ due to the accumulation of lactic acid in the muscles as a result of the process of diabetic decomposition. Most researchers noted that there was a significant fall in $\mathrm{pH}$ values when electrical stimulation was applied to laying hens (Gault et al., 2000), turkeys (Kannan et al., 1991) and broiler and ducks (Alvarado \& Sams, 2000).

In another study, no a significant effect was observed on the $\mathrm{pH}$ values of meat (Young \& Buhr, 2000). Haj-Saeed (2004) on a study conducted on elderly laying hens, it was found there was a significant effect of electrical stimulation $(p<0.01)$ on decreasing $\mathrm{pH}$ value. Moreover, researchers found a sort of fall in $\mathrm{pH}$ as long as there is an increase in stimulation time within a single voltage .

Sams (1990) didn't find any significant effect of increasing the stimulation time on the $\mathrm{pH}$. The use of electrical stimulation in the slaughtered speeds up the rate of $\mathrm{pH}$. Glycogenolysis is accelerated after slaughter which is due to stimulation of the effectiveness of glycogenolysis. Al-Hmedawy (2019) found significant differences in $\mathrm{pH}$ values and slaughtered bird temperature during electrical stimulation at 3.67 and 7.33 V.cm ${ }^{-1}$ electric field intensity. Postmortem glycolysis was accelerated production of lactic acid by using electrical stimulation which led to reduce meat $\mathrm{pH}$ lower than 6 before the temperature of muscle to arrive 10 ${ }^{\circ} \mathrm{C}$ (Lang et al., 2016). 
Effect of Electrical Stimulation on the liquid loss during storage

Exuding fluid is a liquid-like liquid that comes out of fresh meat during being stored and from frozen meat during being melted (Al-Fayyadh \& Naji, 1989). The increase of exuded liquid and an increase in proportion of nutrients lost with the growing age of the bird and the thickness of the muscle. As long as a muscle is thick, an amount of exuding liquid increases. Kim et al. (2008) concluded that amount of loss from exuded fluid of chicken meat increased by $29.2 \%$, while the rate of loss in duck meat was $34.5 \%$. The percentage of protein in exuded fluids also rises due to the protein denaturation (den Hertog-Meishke et al., 1997).

\section{Chemical characteristics}

\section{Effect of electrical stimulation on lipid oxidation}

A few studies were conducted on red meat and just recently done to understand the relationship between lipid oxidation and eating quality of meat treated with electrical stimulation. Cheng \& Ockerman (2013) evaluated the effects of electrical stimulation on rate of lipid oxidation and wormed-over flavour in precooked roast beef after refrigerated storage and reheating, they showed that electrical stimulation had no significant effect on lipid oxidation or formation of thiobarbituric acid reactive substances in pre-cooked roast beef. However, there was an increased undesirable warmed-over flavour for both electrical stimulation and non- electrical stimulation treatments over refrigerated storage time. Riffin et al. (2019) investigated the effect of electrical stimulation on the oxidation of alpaca (Vicunga pacos) meat and showed that although electrical stimulation increased lipid oxidation within the longissimus, overall oxidation levels were extremely low and could not be detected by the consumers. For poultry, there is no published study on the effect of electrical stimulation on lipid oxidation .

\section{Physical characteristics}

Effect of electrical stimulation on the
chicken temperature

There is a lack of study on the effect of electrical stimulation on the temperature of poultry carcasses. For red meat, Carse (1973) reported that beef carcass temperature dropped from $40^{\circ}$ to $37^{\circ} \mathrm{C}$ during electrical stimulation. However, Bendall (1980) reported that mean temperature of whole beef carcasses rose by approximate $0.04{ }^{\circ} \mathrm{C}$. The increases in carcass temperature treated with electrical stimulation have been attributed to accelerate glycolysis after passage of electricity through carcasses.

\section{Effect of electrical stimulation on the colour}

Many researchers have reported that electrical stimulation has a significantly affect colour in red meat (Asghar et al., 1983, Adeyemi \& Sazili, 2014; Polidori \& Vincenzetti 2017), although the results varied with study. Similar results are also reported with electrical stimulation of poultry carcasses. Maki \& Froning (1987) studied the quality effect of post-mortem electrical stimulation (after bleeding and prior to scalding) on turkey breast meat. They reported that electrical stimulation significantly increased meat redness (Hunter Lab values) in uncooked breast muscle and decreased lightness in the cooked breast muscle. Froning \& Uijttenboogart (1988) treated broiler carcasses with post-mortem intermittent electrical stimulation for $60 \mathrm{~s}(100 \mathrm{~V}$ immediately after bleeding) and breast meat 
were deboned at various times (0 to $240 \mathrm{~min}$ ) after evisceration. They found that there was the significant method of deboning time interaction. Raw breast muscle from electrical stimulation muscle was significantly darker in colour (lower $\mathrm{L}^{*}$ value) when the meat was hot-boned at $60 \mathrm{~min}$ or earlier. However, there were no significant differences in lightness ( $\mathrm{L}^{*}$ values) of the treatments beyond the 60-min deboning time. Electrical stimulation resulted in the meat lighter (greater $\mathrm{L}^{*}$ values) in non-deboned muscle at all times after evisceration. In addition, the electrical stimulation significantly increased redness ( $\mathrm{a}^{*}$ values) at all deboning times except $30 \mathrm{~min}$. However, non-deboned electrical stimulation muscle appeared redder (greater $\mathrm{a}^{*}$ values) at all times. Electrical stimulation did not consistently affect yellow (b* values) compared with those of untreated birds .

Owens \& Sams (1997) evaluated the effects of electrical stimulation on muscle metabolism and breast meat quality in turkeys. turkey hens were electrically stimulated at the neck in a saline bath $(570 \mathrm{~V}$, $450 \mathrm{~mA}, \mathrm{AC}, 60 \mathrm{~Hz}, 2 \mathrm{~s}$ on $1 \mathrm{~s}$ off for 10 pulses). Their results showed that there was no significant difference in raw meat redness between treatments and no significant effect on meat lightness of the fillets between treatments at boning time at $24 \mathrm{~h}$ postmortempost-mortem. Owens \& Sams (1998) further evaluated the effects of electrical stimulation on broiler pectoralispectorals major harvested at $1 \mathrm{~h}$ post-mortem and individually quick frozen or aged on ice. In experiments, birds were treated with similar electrical stimulation parameters at the neck in a saline bath. The researchers found that there was no significant difference in lightness and redness in raw breast meat between the electrical stimulation treatments or control at 1 or $24 \mathrm{~h}$. Sams \& Dzuik (1999) found that the combination of argon gas and electrical stimulation resulted in redder meat.

Craig et al. (1999) studies the combined effects of antemortem electrical stunning and postmortem electrical stimulation on broiler breast muscle rigor development and meat quality attributes. The researchers found that here were no significant interactions between trial, stunning, stimulation, or deboning time. Electrical stimulation with $440 \mathrm{~V}$ resulted in darker, less yellow (lower $b^{*}$ value) and redder raw meat in the breast samples. Castaneda et al. (2005) evaluated the functionality of broiler breast meat of electrically stimulated carcasses with and without normal rapid chilling and found no differences in lightness of raw breast meat between the treated and non-treated samples regardless of carcass chilling method. Lyon et al. (1989) evaluated the effects of the combination of electrical stimulation and marination on colour of both raw and cooked frozen/thawed broiler breast meat deboned at four post-mortem times $(0,0.5,1.0$, and $1.5 \mathrm{~h}$ post-mortem). The results showed that raw muscles from stimulated carcasses were significantly redder than muscles from nonstimulated carcasses, while the raw meat lightness and yellowness between stimulated and non-stimulated carcasses were not significantly different. Cooked meat from stimulated carcasses was darker and redder than meat from non-stimulated carcasses. Young et al. (1999) also investigated the effects of interaction between electrical stimulation and marination on interior colour of cooked muscle and showed that meat lightness, redness and yellowness $\left(\right.$ CLEL $\left.* a^{*} b^{*}\right)$ were not significantly affected by the interactions. However, electrical stimulation resulted in significantly greater 
lightness and less redness $\left(\mathrm{a}^{*}\right)$ of cooked breast meat. Aging time and electrical stimulation significantly affected colour measurements. Marinated treatment only affected b* values. Perlo et al. (2012) found significant interactions of electrical stimulation, marination, and aging time. In both marinated and non-marinated fillets, electrical stimulation treatment increased meat lightness. Aging times increased lightness in fillets aged $8 \mathrm{~h}$ compared to $0 \mathrm{~h}$ in all treatments (electrically-stimulated and non- electrically-stimulated, marinated and non-marinated). There were also significant differences in redness and yellowness with aging time. Marinated treatment decreased yellowness in both electrical stimulation and non- electrical stimulation fillets. The differences between these studies have been ascribed to differences in stimulation, aging time, or measurement methods (Owens \& Sams, 1997, 1998).

The effects of electrical stimulation on meat colour have been attributed to a fast drop in $\mathrm{pH}$ and the oxidation of myoglobin (Ledward et al., 1986) and may be its capability to reduce metabolites of surviving oxidative pathways in the muscle (Contreras \& Harrison, 1981; Lawrie \& Ledward, 2006). In broiler breast meat, although the impact of electrical stimulation on meat quality is not consistent, most studies demonstrate that electrical stimulation results in rapid $\mathrm{pH}$ decline. In addition, it is inconclusive about the effects of electrical stimulation on incidence rate of pale, soft and exudative (PSE) in both red meat and poultry breast meat, even though it enhances the rate of glycolysis in muscle (Adeyeni \& Sazili, 2014; Castenoda et al., 2005; Polidori \& Vincenzetti, 2017). Hafid et al. (2018) declared that the electrical stimulation period had a significant effect on the colour of
Muscovy duck meat and the period of $20 \mathrm{~min}$. was better than the other periods. AlHmedawy et al. (2019). Stated that the Electrical stimulation had a significant ( $p<0.05)$ effect on the color compounds (lightness, redness and yellowness)

\section{Effect of electrical stimulation on water- holding capacity}

The effects of electrical stimulation on waterholding capacity (WHC) of poultry meat differ from study to study. With turkey, Maki \& Froning (1987) did not note any differences in cook loss of whole carcasses and in expressible moisture of both turkey breast and thighs between electrically-stimulated and non-electrically-stimulated samples. Owens \& Sams (1998) also measured the effects of electrical stimulation on expressible moisture and cook loss of turkey pectoralis major. The data showed that there was no consistent effect of electrical stimulation on expressible moisture or cook loss. Both of them varied with postmortem harvest time and replications. Froning \& Uijttenboogaart (1987) found that cooking losses of the cold deboned groups were significantly greater from electrically-stimulated muscle than from muscle of non-treated controls except at the 0min, 15-min, and 60-min deboning times. The electrical stimulation produced significantly greater cooking losses in hot deboned meat at deboning times of 120 and 240 min than in controls. However, expressible moisture of breast muscle was not significantly affected by electrical stimulation or deboning methods. Castenado et al. (2005) did not note any differences in cook loss and expressible moisture of broiler breast meat regardless of carcass chilling method.

Alvarado \& Sams (2000) investigated the effects of electrical stimulation on postmortem physiology and quality of both 
broiler and duck breast meat. The pectoral muscle was harvested from the carcasses after $0.25,1.25$, and $24 \mathrm{~h}$ postmortem. The researchers found that that electrical stimulation decreased cook loss in meat harvested at $1.25 \mathrm{~h}$ postmortem in broiler pectoralis major, whereas no differences were noted at 0.25 and $24 \mathrm{~h}$. However, electrical stimulation did not affect percentage cook loss of duck muscle for any postmortem deboning time. Dickens \& Lyon (1995) studied the effects of stimulating broilers on biochemical reactions and objective texture of the meat deboned after 1,2 , or $3 \mathrm{~h}$ in the chiller and did not found any cook loss differences in breast meat from the unstimulated and stimulated carcasses. Young \& Lyon (1997) reported that electrical stimulation did not affect moisture absorption during chilling. However, cooking loss was dependent upon time of aging and electrical stimulation. For the unstimulated carcasses, cooking loss remained constant regardless of aging time, but was elevated for those electrical stimulation carcasses that were aged more than 30 min. Zocchi \& Sams (1999) compared cook loss of meat treated with electrical stimulation and deboned at $2 \mathrm{~h}$ postmortem with cook loss of meat deboned at $4 \mathrm{~h}$ postmortem and found no difference due to electrical stimulation or deboning time for either thaw loss or cook loss .

Young et al. (1999) found that cooking loss was not significantly affected by interactions among aging time, marination and electrical stimulation and the electrical stimulation resulted in significant increases in cook loss of broiler breast meat, although electrical stimulation improved marinade absorption. Young et al. (2005) conducted experiments to determine the effects of carcass electrical stimulation and alternative carcass chilling methods on yield of early-harvested boneless broiler pectoralis major and reported that either the electrical stimulation treatment or chilling method did not influence harvest breast meat weight and cooked meat weight. However, meat cooked yield was significantly impacted by both the electrical stimulation treatment and chilling method. Breast meat from treated carcasses exhibited significantly greater cooked yields than the meat from nontreated carcasses. Perlo et al. (2012) found that cook loss was significantly influenced by aging time, electrical stimulation, marination, and electrical stimulation $\times$ aging time interaction. In non-marinated pectoralis major, the electrical stimulation treatment reduced cook loss in meat aged for 0, 2 and 4 h. In marinated fillets the electrical stimulation treatment decreased cook loss at 2, 4, 6 and $8 \mathrm{~h}$ of aging. Marination decreased cook loss of treated meat aged for 4, 6 and $8 \mathrm{~h}$ compared to non-marinated control, while no marination effect was observed in nonstimulated breast meat.

Kranen (2003) reported no significant differences in tissue fluid loss due to applying electrical stimulation after feather removal and concluded that the electrical treatment did not negatively affect water-holding capacity of the meat. Lyon et al. (1989) evaluated three electrical potentials $(50,200$ and $350 \mathrm{~V}$ AC) in stimulation of broilers during bleeding. Pectoralis major from broilers subjected to the $350 \mathrm{~V}$ stimulation treatment exhibited the lowest cooked yield and the greatest percentage of fluids and solids lost during heating than samples from broilers subjected to $50 \mathrm{~V}$ stimulation. There was no significant difference in cooked yield or percentage loss of fluids and solids for breast meat from carcasses subjected to the 50 or 200 V. Gault et al. (2000) investigated the influence of different rates of wing flapping on the rate of post-mortem glycolysis in the 
pectoralis major of commercially-processed broilers. Broiler carcasses were treated with 300 pulses of low voltage electrical stimulation shortly after slaughter at various frequencies and pulse widths. Results showed that pulse frequency had no effect on cooking loss of breast meat compared to controls.

\section{Effect of electrical stimulation on meat shelf life during storage}

No research has been carried out to evaluate shelf life of poultry meat products treated with electrical stimulation. In red meat, quality examination showed some difference in surface discolouration and overall appearance of the retail cuts from electrically stimulated and control lamb carcass (Riley et al., 1980). Previous studies also demonstrated that electrical stimulation enhanced retail case life or meat acceptability of cut steaks (Savell et al., 1977). Rashid et al. (1983) did not measure any significant difference in colour of ovine muscle, which were wrapped in oxygen permeable film and displayed under commercial conditions, between stimulated and unstimulated samples .

Effect of electrical stimulation on the microorganisms

\section{Mechanism of microorganism's inactivation using electrical stimulation}

Electroporation theory suggests that the high electrical field intensity leads to increase cell membrane permeability due to occur holes in the membranes. Moreover, an imbalance occur in osmotic balance during electroporation due to the leakage of ions and small particles into the cell and thus the membrane becomes preamble for the water that causes the swelling and disruption cell as shown in fig. (2) (Tsong, 1990). Castro et al. (1993) reported that the electroporation causes an instability of the binary layer (fat and protein) in the cell membranes and the small particles and water penetrate it and causes collapsing cell.

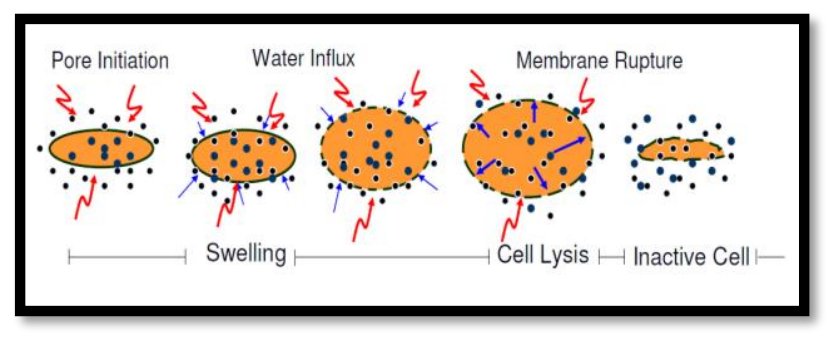

Fig. (2): Stages of electroporation in the cell membrane (Tsong, 1990).

The reduction of microorganisms during applying the electrical field can be calculated by equation 1 (Food \& Drug Administration, 2000):

$$
\log \left[\frac{D}{D_{R}}\right]=\frac{-\left(E-E_{R}\right)}{Z}
$$

Where, $\mathrm{D}$ is the time required to reduce microorganisms by $90 \%$ through one logarithmic cycle, $D_{R}$ is the time of decimal reduction at intensity of specific electrical field $\left(E_{R}\right)$ and $z$ is the increment in the intensity of electrical field to decrease of $D$ by one logarithmic cycle. E is the electric field intensity.

Although the effect of electrical stimulation on the microbiology of meat has been widely investigated in red meat (Asghar et al., 1983,; Palaniappan \& Sastry, 1990; Adeyemi \& Sazili, 2014;; Polidort \& Vincenzetti, 2017), there is only very limited information available in poultry (Li et al., 1993) and the research was exclusively limited to Salmonella typhimutium and carried out in the same laboratory .

Slavik et al. (1990) evaluated electrical stimulation for eliminating or reducing the number of $S$. typhimurium attached to chicken legs and the effect of electrical stimulation on bacteria in an electrolyte solution for 
preventing cross-contamination of poultry carcasses during processing. Their data showed that electrical stimulation was effective in killing bacteria in the electrolyte solution and in reducing the number of Salmonella attached to chicken legs when legs are attached to anodes. Li et al. (1991) reported that low-voltage, low current pulsed electrical signals was effective for killing bacteria in various electrolyte solutions and in poultry chiller water. Their study further showed that $S$. typhimutium attached to chicken skins were reduced by $90 \%$ or more after electrical treatment in the electrolyte solutions for $10 \mathrm{~min}$ and the effectiveness varied with composition of solution. The researchers concluded that the combined electrical and chemical treatments reduced variation in bacterial reduction and electrical stimulation in combination with a food additive in solution can be used as an alternative method for reducing $S$. typhimurium attached to chicken carcasses as well as tenderization of meat ( $\mathrm{Li}$ et al. 1994b).

The mechanisms bacterial death by electricity may be due to mechanical, chemical, or thermal effects, or to their combination, but they are not yet determined clearly and are not fully understood (Palaniappan \& Sastry, 1990). The antimicrobial effects have been attributed to the electrical stimulation deleterious effect on either the bacterial cells by affecting the viability or on the meat as a growth medium by fast reduction in $\mathrm{pH}$ value (Riley et al., 1980). Another hypothesis was that the proteolytic enzymes released during electrical stimulation may be destroying the bacteria. The change in redox potential and presence of free radicals may also be responsible for inactivating bacterial cells in meat from electrically stimulated carcasses (Mrigadat et al., 1980). Al-Hmedawy et al. (2018) disclosed that the effect of electrical stimulation (110 and 240 volts) on the number of Psychrophiles, lipolysis and proteolysis was significant ( $\mathrm{p}<0.05$ ), and 240 volts gave higher reducing the microorganisms in both chicken and duck.

\section{Effect of electrical stimulation on poultry meat organoleptic}

Unlike red meat (Asghar et al., 1983; Adeyemi \& Sazili, 2014; Polidori \& Vincenzetti, 2017), there was very limited study on the effects of electrical stimulation on sensory quality of poultry meat. In study on the influence of commercial-scale electrical stimulation on tenderness and meat yield production costs, Hischiller \& Sams (1998) evaluated sensory quality of electrically-stimulated chicken breast using a 9-member panel and a 5-point scale. Sensory panel responses indicated that more treated meat was perceived "slight tender" than the $2 \mathrm{~h}$ non-stimulated controls. Electrical stimulation combined with the injection treatment resulted in meat as tender as that deboned from control carcasses at $8 \mathrm{~h}$ postmortem. Dickens \& Lyon (1995), based on the data of the relationship between sensory perception of tenderness and instrumental shear measurements from a separate experiment (Lyon \& Lyon, 1991), predicted that the non-treated breast meat was consistently less tender than the treated samples regardless of postmortem deboning ime. Young \& Lyon (1997) also predicted that unstimulated broiler breast was undesired by the consumers compared with stimulated muscles, and concluded that electrical stimulation in combination with $\mathrm{NaCl}_{2}$ increased quality of meat and it was desired by the consumers. Table (1) summarized the 
effect of electrical stimulation on the qualitative properties of poultry meat.

Table (1): Summarizes the effect of electrical stimulation on the qualitative properties of poultry meat.

\begin{tabular}{|c|c|c|c|}
\hline $\begin{array}{c}\text { Sample } \\
\text { description }\end{array}$ & $\begin{array}{c}\text { Stimulation } \\
\text { parameters } \\
\text { (voltage/Ampere / } \\
\text { time) }\end{array}$ & Effects of stimulation & References \\
\hline Broiler breast & $\begin{array}{l}240,530,820 \mathrm{~V} \text { and } \\
\text { low voltage } 45 \mathrm{~V} / 2- \\
3 \mathrm{~min} .\end{array}$ & $\begin{array}{l}\text { High voltage significantly } \\
\text { increased shear values, declined } \\
\text { sarcomere length and acceptance } \\
\text { tenderness of chill boned fillets. } \\
\text { low voltage improve tenderness } \\
\text { of hot boned fillets. }\end{array}$ & $\begin{array}{l}\text { Thompson et al. } \\
\text { (1987) }\end{array}$ \\
\hline Turkey Meat & $\begin{array}{l}800 \mathrm{~V} / 430 \mathrm{~mA} / \\
36 \mathrm{~s} / \text { pules }(4 \mathrm{sec} \mathrm{ON}, \\
5 \mathrm{sec} \text { OFF) }\end{array}$ & $\begin{array}{l}\text { Decreased } \mathrm{pH} \text { and shear force. } \\
\text {, No significant effect on the } \\
\text { cooking loss, breast moisture and } \\
\text { tight moisture. No significant } \\
\text { effect on the L-value (lightness) }\end{array}$ & $\begin{array}{l}\text { Maki \& Froning } \\
\text { (1987) }\end{array}$ \\
\hline broiler meat & $\begin{array}{l}100 \mathrm{~V} / \text { pulse }(1 \mathrm{sec} \\
\mathrm{ON}, 0.5 \mathrm{sec} \mathrm{OFF}, \\
\text { for } 90 \mathrm{sec})\end{array}$ & $\begin{array}{l}\text { Did not improve the tenderness } \\
\text { of flanged muscles. Enhanced } \\
\text { elasticity of the flanged muscles. } \\
\text { Decreased lightness. }\end{array}$ & $\begin{array}{c}\text { Froning \& } \\
\text { Uijttenboogaart } \\
(1988)\end{array}$ \\
\hline boiler meat & $50 \mathrm{~V}$ & Did not improve tenderness. & Lyon et al. (1989). \\
\hline $\begin{array}{l}\text { Spent chicken } \\
\text { carcasses. }\end{array}$ & 220 or $330 \mathrm{~V}$ & $\begin{array}{l}\text { Decreased the diameter of } \mathrm{K} \\
\text { muscle fibers. }\end{array}$ & Kannan et al. (1991) \\
\hline $\begin{array}{l}\text { chicken } \\
\text { breast }\end{array}$ & $\begin{array}{l}450 \mathrm{~mA} / \mathrm{bird} / 2 \mathrm{sec} \\
\text { ON, } 1 \mathrm{sec} \text { OFF, } 5 \\
\text { pulses) }\end{array}$ & Decreased $\mathrm{pH}$ & $\begin{array}{l}\text { Young \& Lyon } \\
\quad(1997)\end{array}$ \\
\hline Turkeys & $\begin{array}{l}570 \mathrm{~V} / 450 \\
\mathrm{~mA} / 60 \mathrm{~Hz} /(2 \mathrm{~s} \text { on, } 1 \\
\text { sec off for } 10 \\
\text { pulses })\end{array}$ & $\begin{array}{l}\text { Reduced } \mathrm{pH} \text {, accelerated rigor } \\
\text { mortis. }\end{array}$ & $\begin{array}{l}\text { Owens \& Sams } \\
\quad(1997)\end{array}$ \\
\hline breast meat & $\begin{array}{l}450 \mathrm{~mA} / \mathrm{bird}, 7 \\
\text { pulses, } 2 \mathrm{sec} \mathrm{ON}, 1 \\
\text { sec OFF) }\end{array}$ & Improved tenderness & $\begin{array}{c}\text { Hirschler \& Sams } \\
\text { (1998) }\end{array}$ \\
\hline Broilers meat & $\begin{array}{l}200 \mathrm{~V} / 115-125 \mathrm{~mA} \\
1 \mathrm{sec} \text { OFF: } 2 \mathrm{sec} \mathrm{ON} \\
\text { AC, for } 1 \mathrm{~min} .)\end{array}$ & $\begin{array}{l}\text { Gave more } \quad \text { tenderness } \\
\text { (stimulation after cooling). No } \\
\text { significant } \text { effect } \quad \text { (only } \\
\text { stimulation). }\end{array}$ & Young et al. (1999) \\
\hline Broiler breast & $56 \mathrm{~V} / 35 \mathrm{~mA} / 2 \mathrm{sec}$ & Decreased toughness, acceptable & Zocchi \& Sams \\
\hline
\end{tabular}


Al-Hilphy et al./ Basrah J. Agric. Sci., 33(1): 135-158, 2020

\begin{tabular}{|c|c|c|c|}
\hline fillets & on, $1 \mathrm{~s}$ off & $\begin{array}{l}\text { tenderness, reduced the required } \\
\text { time by } 50 \% \text {. }\end{array}$ & (1999) \\
\hline broiler meat & $\begin{array}{l}370 \mathrm{~V} / 580 \\
\mathrm{~mA} / \mathrm{pulse}(2 \mathrm{sec} \\
\mathrm{ON}, 1 \mathrm{sec} \mathrm{OFF})\end{array}$ & $\begin{array}{l}\text { Reduced } \mathrm{pH} \text { and increased the } \\
\text { cut-off values after } 1.25 \text { hours of } \\
\text { slaughter. }\end{array}$ & $\begin{array}{l}\text { Alvarado \& Sams } \\
\qquad(2000)\end{array}$ \\
\hline boiler meat & $100 \mathrm{~V}$ & Decreased $\mathrm{pH}$ & Gault et al. (2000) \\
\hline $\begin{array}{l}\text { chicken } \\
\text { breast fillets }\end{array}$ & $\begin{array}{l}200 \text { volts, } 115-125 \\
\mathrm{~mA} / \mathrm{bird}, \mathrm{AC}, 2 \mathrm{sec} \\
\text { ON: } 1 \mathrm{sec} \mathrm{OFF})\end{array}$ & $\begin{array}{l}\text { Reduced liquid loss. No effect on } \\
\text { the } \mathrm{pH} \text {. }\end{array}$ & $\begin{array}{l}\text { Young \& Buhr } \\
\quad(2000)\end{array}$ \\
\hline Broiler & $\begin{array}{l}370 \mathrm{~V} / 450 \\
\mathrm{~mA} / 60 \mathrm{~Hz} /(2 \mathrm{on}, 1 \\
\text { off pules) }\end{array}$ & $\begin{array}{l}\text { Reduced } \mathrm{pH} \text { of muscles, shear } \\
\text { values. and gravimetric } \\
\text { fragmentation index. Increased } \\
\text { cut-off values. }\end{array}$ & $\begin{array}{c}\text { Alvarado \& Sams } \\
\text { (2000) }\end{array}$ \\
\hline Broiler meat & $\begin{array}{l}450 \mathrm{mV} / 450 \mathrm{~mA} / 2 \\
\mathrm{~s} . / 7 \mathrm{pulse} / \mathrm{s}\end{array}$ & $\begin{array}{l}\text { Enhanced meat tenderness, } \\
\text { decreased ATP, } \mathrm{pH} \text { and muscle } \\
\text { fibre physical rupture. not any } \\
\text { differences in cooking loss }\end{array}$ & $\begin{array}{l}\text { Canstaneda et al. } \\
\text { (2005) }\end{array}$ \\
\hline Spent Rabbit & $110-220 \mathrm{~V}$ AC. & $\begin{array}{l}220 \mathrm{~V} \text { increased sarcomere length } \\
\text { higher than } 110 \mathrm{~V} \text {. reduced the } \\
\text { manual of muscle fibres' } \\
\text { breakage. No significant effect in } \\
110 \mathrm{~V} \text {. }\end{array}$ & $\begin{array}{l}\text { Apparao, et al. } \\
\text { (2009) }\end{array}$ \\
\hline $\begin{array}{l}\text { Beef } \\
\text { carcasses }\end{array}$ & $800 \mathrm{~V} / 2.5 \mathrm{~A} / 25 \mathrm{~s}$ & $\begin{array}{l}\text { Decreased pH, Changed the } \\
\text { colour. Rigor mortis was } \\
\text { accelerated. }\end{array}$ & $\begin{array}{l}\text { Mombeni et al. } \\
\text { (2013) }\end{array}$ \\
\hline yak meat & $\begin{array}{l}21 \mathrm{~V} / 0.25 \mathrm{~A} / 50 \\
\mathrm{~Hz} / 60 \mathrm{~s}\end{array}$ & $\begin{array}{l}\text { Reduced } \mathrm{pH} . \quad \text { Accelerated } \\
\text { production of lactic acid }\end{array}$ & Lang et al., 2016) \\
\hline $\begin{array}{l}\text { Muscovy } \\
\text { duck meat }\end{array}$ & $20 \mathrm{~V} / 0-20 \mathrm{~min} /$ & $\begin{array}{l}\text { Reduced cooking loss, } \mathrm{pH} . \\
\text { Increased tenderness. }\end{array}$ & Hafid et al. (2018) \\
\hline \multicolumn{2}{|c|}{ Chicken meat $110-220 \mathrm{~V} / 20 \mathrm{~s}$} & \begin{tabular}{llr} 
Significantly & \multicolumn{2}{c}{ reduced } \\
Psychrophiles, lipolysis and \\
proteolysis.
\end{tabular} & $\begin{array}{l}\text { Al-Hmedawy et al. } \\
\text { (2018) }\end{array}$ \\
\hline Chicken mea & $\begin{array}{l}110-220 \mathrm{~V} \\
(7.33 \\
60 \mathrm{~Hz} / 20 \mathrm{~s}\end{array}$ & $\begin{array}{l}\text { Significantly effected on the } \\
\text { length of sarcomere. Increased } \\
\text { muscle fibre breakage. } \\
\text { Significant differences in pH } \\
\text { values }\end{array}$ & 1-Hmedawy (2019) \\
\hline
\end{tabular}

\section{Pulsed electric field stimulation}

Pulsed electric field (PEF) is an emerging non-thermal technique and it considered as a very promising technology of preservation foods and enhancement of food quality. In this technology, the pulsed electric field with 
short duration ranged between several nanosecond to milliseconds using electrical field intensity from 0.1 to $80 \mathrm{kV} . \mathrm{cm}^{-1}$ is applied, and PEF pass through food put between two electrodes (Koubaa et al., 2015; Puértolas \& Barba, 2016; Barba et al. 2018). PEF depends on the electric field intensity, delivered energy and temperature of treatment (Toepfl et al., 2014). Foods treated by PEF had a less degradation of nutrition and sensory compared to the conventional thermal processing (Buckow et al., 2013). The advantage of PEF are lower temperature and processing time (Walkling-Ribeiro et al., 2011). PEF was used to solid food processing ( Aguiló-Aguayo et al., 2017; Liu et al. 2017) and it is use in meat is considered an emerged technique (Bekhit et al., 2016; Ma et al., 2016; Khan et al., 2017; ).

Gudmundsson \& Hafsteinsson (2001) and O'Dowd et al. (2013) reported that the literatures for using PEF in meat is very little. The meat qualitative characteristics treated by PEF was modified as well as curing and brining were improved. Bhat et al. (2018) disclosed that the PEF improves meat tenderness in pre-rigor and post-rigor during aging muscle. There are not literature available about the use of PEF in poultry meat treatment.

The energy density during PEF application is given in equation (2) as follows (Zhang et al., 1995; O'Dowd et al., 2013):

$$
Q=\frac{V^{2} t}{R v}
$$

Where, $\mathrm{Q}$ is the energy density $\left(\mathrm{kJ}^{\mathrm{kg}} \mathrm{kg}^{-1}\right), \mathrm{t}$ is the time of treatment $(\mu \mathrm{s})$ (pulses number $\times$ duration pulse), $\mathrm{V}$ is the voltage $(\mathrm{V}), \mathrm{v}$ is the sample weight $(\mathrm{g})$ and $\mathrm{R}$ is the resistance (Ohm).
For reduction of microorganism using PEF, equation (3) is used to calculate reduction of microorganism (Hulsheger et al., 1981):

$$
\frac{N}{N_{o}}=\left[\frac{t}{t_{c}}\right]^{-\left(E-E_{c}\right) / k}
$$

Where, $\frac{N}{N_{o}}$ is the survival rate, $\mathrm{k}$ is the constant, $t$ is the time of treatment, $t_{c}$ is the critical time (under the time of treatment that no inactivation of microorganisms happens), $\mathrm{E}$ is the electric field strength $\left(\mathrm{V} . \mathrm{cm}^{-1}\right), \mathrm{E}_{\mathrm{c}}$ is the critical electric field strength (the highest electric field strength which does not inactivation of microorganism.

\section{Conclusions}

The meat industry is in line with the consumer's needs for meat with health, safety, and nutritional values and good appearance. Electrical stimulation is one of the novel methods that used to tenderize meat. There are two kinds of electrical stimulation are: low voltage electrical stimulation and high voltage electrical stimulation. Using electrical stimulation and salts together improve meat tenderness more than that of electrically stimulated meat only. Electrical stimulation has the effect of increasing the length of the sarcomere. There was a significant fall $(\mathrm{p}<0.01)$ in the manual of muscle fibre' breakage compared with the control treatment. The low $\mathrm{pH}$ is due to an increase in the stimulation time within one voltage. The electrical stimulation had no significant effect on lipid oxidation. Moreover, the electrical stimulation period had a significant effect on the colour of meat. Cooking losses of the cold deboned groups were significantly greater from electricallystimulated muscle than from muscle of nontreated controls. In addition, electrical stimulation eliminates microorganisms. 


\section{Acknowledgement}

The author's thankful staff Department of Food Sciences and Biotechnology, College of Agriculture, University of Basrah for availableness literature and library.

\section{Conflict interest}

The authors declare that they have no conflict of interests

\section{References}

Adeyemi, K.D. \& Sazili, A.Q. (2014). Efficacy of carcass electrical stimulation in meat quality enhancement: A review. Asian-Austral. J. Anim. Sci., 27(3): 447456.https://doi.org/10.5713/ajas.2013.1346 3

Agbeniga, B. (2018). Effects of timing and duration of low voltage electrical stimulation of light and heavy carcasses on meat quality of South African feedlot cattle. Ph. D. Thesis, Univ. Pretoria: 255pp.

Aguiló-Aguayo, I.; Gangopadhyay, N.; Lyng, J.G.; Brunton, N. \& Rai, D.K. (2017). Impact of pulsed light on colour, carotenoid, polyacetylene and sugar content of carrot slices. Innov. Food Sci. Emerg. Technol., 42, 49-55. https://doi.org/10.1016/j.ifset.2017.05.006

Al-Fayyadh, H.A. \& Naji, S.A. (1989). Poultry Product Technology. $1^{\text {st }}$ ed., Dar Alhekmah Press. Mosul: 626p. (In Arabic).

Al-Fayyadh, H.A.; Naji, S.A.; AbdulHussain, S. \& Al-Hajo, N.N. (2010) Poultry Products Technology. 2nd ed., Part Two, Min.High. Educ. Sci. Res., Univ.Baghdad. 292pp. (In Arabic).

Al-Hmedawy, N.K.; Al-Asadi, M.H. \& AlHilphy, A.R. (2019). Effect of electric stimulation on histological traits and color of carcasses in old duck and chicken. In IOP Conference Series: Earth Env. Sci. 388(1) 012024. IOP Publishing .

Al-Hmedawy, N.K. (2019). Effect of electric stimulation on some the quality characters of meat chicken carcasses and domesticated old Ducks. M. Sc. Thesis, Coll. Agric., Univ. Basrah: 90pp. (In Arabic).

Al-Hmedawy, N.K.; Al-Asadi, M.H. \& AlHilphy, A.R. (2018). Destruction of bacteria using electric stimulation of old Duck and Chicken carcasses. Basrah J. Agric. Sci., 31(2): 31-35. https://doi.org/10.37077/25200860.2018.9 7 .

Al-Rubaiya, A.M.S.; Al-Kaisey, M.T. \& AlJalili, Z.F. (2006). Improvement of meat quality characteristics of aged female goats by electrical stimulation and salt solutions. Iraqi J. Biotech., 5(1): 20-37. (In Arabic).

Al-Rubaiya, A.M. S.; Al-Kaisey, M.T. \& AlJaili, Z.F. (2010). Effect of electrical stimulation and salt infusion proteins and free fatty acids content of carcasses aged female goats. Int. J. Sci. Tech., 143(595): 1-26. (In Arabic).

Alvarado, C.Z. \& Sams, A.R. (2000). The influence of post mortem electrical stimulation on rigor mortis development, calpastatin activity, and tenderness in broiler and duck pectoralis .Poult. Sci., 79: 1364-1368.

https://doi.org/10.1093/ps/79.9.1364

Apparao, V.; Wilfred, R.S. \& Kalaikannan, A. (2009). Effect of electrical stimulation on structural characteristics of spent rabbit carcass. Global Vet., 3(4): 292-296.

Asghar, A. \& Pearson, A.M. (1980). Influence of ante- and postmortem treatments upon muscle composition and 
meat quality. Adv. Food Res., 26: 53-213. https://doi.org/10.1016/S00652628(08)60318-3

Asghar, A.; Henrickson, R.L. \& Kastner, C.L. (1983). Post-mortem stimulation of carcasses: effects on biochemistry, biophysics, microbiology, and quality of meat. CRC Crit. Rev. Food Sci. Nutri., $18(1)$, $1-58$. https://doi.org/10.1080/104083982095273 56

Barba, F.J.; Ahrne, L.; Xanthakis, E. Landerslev, M.G. \& Orlien, V. (2018). Innovative Technologies for Food Preservation. 25-51. In: Barba, F.J.; Sant'Ana, A. de S.; Orlien, V. \& Koubaa, M. (Eds.). Innovative Technologies for Food Preservation-Inactivation of Spoilage and Pathogenic Microorganisms. Academic Press, Elsevier Inc.: 326pp. https://doi.org/10.1016/B978-0-12811031-7.00002-9

Bekhit, A.E.D.A.; Carne, A.; van de Ven, R. \& Hopkins, D.L. (2016). Effect of repeated pulsed electric field treatment on the quality of hot-boned beef loins and topsides. Meat Sci., 111: 139-146. https://doi.org/10.1016/j.meatsci.2015.09.0 01

Bendall, J.R. (1980). The Electrical Stimulation of Carcass Meat Animals. 3757 In Lawrie, R.A. (Ed.). Development in Meat Science. Vol2. Applied Science Publ.: 299pp.

Bhat, Z.F.; Morton, J.D.; Mason, S.L. \& Bekhit, A.E.D.A. (2018). Applied and emerging methods for meat tenderization: A comparative perspective. Comp. Rev. Food Sci. F., 17(4): 841-859. https://doi.org/10.1111/1541-4337.12356
Bhat, Z.F.; Morton, J.D.; Mason, S.L. \& Bekhit, A.E.D.A. (2019). Current and future prospects for the use of pulsed electric field in the meat industry. Crit. Rev. Food Sci. Nutr., 59(10): 1660-1674. https://doi.org/10.1080/10408398.2018.14 25825

Birkhold, S.G. \& Sams, A.S. (1993). Fragmentation, tenderness, and postmortem metabolism of early-harvestd broiler breast fillets from carcasses treated with electrical stimulation and muscle tensioning. Poultry Sci., 72: 577-582. https://doi.org/10.3382/ps.0720577.

Birkhold, S.G. \& Sams, A.S. (1995). Comparative ultrastructure of Pectoralis fibers from electrically stimulated and muscle tensioned broiler carcasses. Poultry Sci. 74: 194-200. https://doi.org/10.3382/ps.0740194

Birkhold, S.G.; Janky, D.M. \& Sams, A.S. (1992). Tenderization of early-harvested broiler breast fillets by high-voltage postmortem electrical stimulation and muscle tensioning. Poultry Sci., 71: 2106-2112. https://doi.org/10.3382/ps.0712106.

Buckow, R.; Ng, S. \& Toepfl, S. (2013). Pulsed electric field processing of orange juice: A review on microbial, enzymatic, nutritional, and sensory quality and stability. Compr. Rev. Food Sci. Food Safety, $\quad$ 12(5): 455-467. https://doi.org/10.1111/1541-4337.12026

Carse, W.A. (1973). Meat quality and the acceleration of post-mortem glycolysis by electrical stimulation. Food Technol., 8: 163. https://doi.org/10.1111/j.13652621.1973.tb01702.x

Castaneda, M.P.; Hirschler, E.M. \& Sams, A.R. (2005). Functionality of electrically 
stimulated broiler breast meat. Poultry Sci. 84: 479.

https://doi.org/10.1093/ps/84.3.479

Castro, A.; Barbosa-Canovas, G.V. \& Swanson, B.G. (1993). Microbial inactivation of foods by pulsed electric fields. J. Food Process. Pres., 17: 47-73. https://doi.org/10.1111/j.17454549.1993.tb00225.x

Cheng, J.H. \& Ockerman, H.W. (2013). Effects of electrical stimulation on lipid oxidation and warmed-over flavor of precooked roast beef. Asian-Austral. J. Anim. $\quad$ Sci., 282. https://doi.org/10.5713/ajas.2012.12419

Contreras, S. \& Harrison, D.L. (1981). Electrical stimulation and hot boning: color stability of ground beef in a model system. J. Food Sci., 46: 404. https://doi.org/10.1111/j.1365-

2621.1981.tb04886.x

Craig, E.W.; Fletcher, D.L. \& Papinaho, P.A. (1999). The effects of ante-mortem electrical stunning and post-mortem electrical stimulation on biochemical and textural properties of broiler breast meat. Poultry Sci., $\quad 78$ : 490. https://doi.org/10.1093/ps/78.3.490

Davey, C.L. \& Winger, R.J. (1988). Muscle to Meat: Biochemical Aspect. 3-31. In: Cross, H.R \& Overby, A.J. (Eds.). Meat Science, Milk Science and Technology Elsevier Sci. Publ., New York: 458pp.

den Hertog-Meischke, M.J.A.; Smulders, F.J.M.; Van Logtestijn, J.G. \& Van Knapen, F. (1997). The effect of electrical stimulation on the water-holding capacity and protein denaturation of two bovine muscles. J. Anim. Sci., 75: 118-124. https://doi.org/10.2527/1997.751118x
Dickens, J.A. \& Lyon, C.E. (1995). The effects of electric stimulation and extended chilling times on the biochemical reactions and texture of cooked broiler breast meat. Poult. $\quad$ Sci., 74: 2035. https://doi.org/10.3382/ps.0742035.

Eikelenboom, G., Smulders, F.J.M. \& Ruderus, H. (1985). The effect of high and low voltage electrical stimulation on beef quality. Meat Sci., 15: 247-254. https://doi.org/ 10.1016/03091740(85)90080-4

Fehrman, C.; Grubbs, K.; Underwood, K. \& Blair, A. (2019). Impact of two levels of low voltage electrical stimulation on beef quality. Meat Muscle Biol., 3(2): 71-71.

Food and Drug Administration (2000). Kinetics of microbial inactivation for alternative food processing technologies. FDA Cent. Food Saf. Appl. Nutr. report-A report of the IFT for the FDA of the US Dep. Health Human Serv. June, 2. 108pp.

Froning, G.W. \& Uijttenboogaart, T.G. (1988). Effect of post-mortem electrical stimulation on color, texture, $\mathrm{pH}$, and cooking losses of hot and cold deboned chic-ken broiler breast meat. Poult. Sci., 67: 1536-1544. https://doi.org/10.3382/ps.0671536

Gault, N.F.S.; Burns, C.; Tolland, E.L.C. \& Kilpatrick, D.J. (2000). Effect some electrical stimulation variables on wing flapping, post-mortem glycolysis and eating quality characteristics of broiler Pectoralis major muscle. Br. Poult. Sci.,41: 293-299. https://doi.org/10.1080/000716600501331 16

Gudmundsson, M. \& Hafsteinsson, H. (2001). Effect of electric field pulses on microstructure of muscle foods and roes. 
Trends Food Sci. Technol., 12(3-4), 122$128 . \quad$ https://doi.org/10.1016/S09242244(01)00068-1

Hafid, H.; Napirah, A. \& Sarifu, S.M. (2018). Effect of electrical stimulation on physical and organoleptic properties of Muscovy duck Meat. J. Ilmu Ternak dan Vet., 23(4), 202-209.

http://doi.org/10.14334/jitv.v23i4.1914

Haj-Saeed, B.A. (2004). The Use of Electrical Stimulation in Tenderizing Spent Hens Meat. Ph. D thesis, Coll. Agric. Univ. Baghdad: 140pp. (In Arabic).

Hirschler, E.M. \& Sams, A.R. (1998). The influence of commercial-scale electrical stimulation on tenderness, breast meat yield, and production costs. J. Appl. Poult. Res., 7 : 99-103. https://doi.org/10.1093/japr/7.1.99

Leon, K., Mery, D., Pedreschi, F., \& Leon, J. (2006). Color measurement in $L * a * b *$ units from RGB digital images. Food research international, 39(10), 1084-1091. https://doi.org/10.1016/j.foodres.2006.03.0 06

Hulsheger, H.; Potel, J. \& Niemann, E.-G. (1981). Killing of bacteria with electric pulses of high field strength. Radiat. Environ. Biophys., 20(1): 53-65. https://doi.org/10.1007/bf01323926

Jassim, J.M.; Mossa, R.K.; Al-Assadi, M.H. \& Gong, Y. (2011). Evaluation of physical and chemical characteristics of male and female ducks carcasses at different ages. Pak. J. Nutr., 10: 182-189.

Kannan, G.; Radhakrishnan, K.T. \& Shanmugam, A.M. (1991). Effect of electrical stimulation on $\mathrm{pH}$, water holding capacity, and fiber diameter and sarcomere length of spent chicken carcasses. Indian Vet. J., 68: 455-459.

Khan, A.W. \& Nakamura, R. (1970). Effect of pre- and post-mortem glycolysis of poultry tenderness. J. Food Sci., 35: 266$267 . \quad$ https://doi.org/10.1111/j.13652621.1970.tb12157.x

Khan, A.A.; Randhawa, M.A.; Carne, A.; Ahmed, I.A.M.; Barr, D.; Reid, M. \& Bekhit, A.E.D.A. (2017). Effect of low and high pulsed electric field on the quality and nutritional minerals in cold boned beef $M$. longissimus et lumborum. Innov. Food Sci. Emerg. Technol., 41, 135-143. https://doi.org/10.1016/j.ifset.2017.03.002

Kim, G.D.; Jeong, J.Y.; Moon, S.H.; Hwang, Y.H.; Park, G.B. \& Joo, S.T. (2008). Effects of muscle fibre type on meat characteristics of chicken and duck breast muscle. In 54 ${ }^{\text {th }}$ Int. Cong. Meat Sci. Technol., 54th ICoMST): 10-15.

Koubaa, M.; Rosello-Soto, E.; Šic Žlabur, J.; Rezek Jambrak, A.; Brncic, M.; Grimi, N., \& Barba, F.J. (2015). Current and new insights in the sustainable and green recovery of nutritionally valuable compounds from Stevia rebaudiana Bertoni. J. Agric. Food Chem., 63(31): 6835-6846.

https://doi.org/10.1021/acs.jafc.5b01994

Kranen, R.W. (2003). Rapid Rigor: The way to accelerate in/line Poultry Processing. In XVI European Symp. Qual. Poult. Meat: 666-671.

Lang, Y.; Sha, K.; Zhang, R.; Xie, P.; Luo, X.; Sun, B. \& Liu, X. (2016). Effect of electrical stimulation and hot boning on the eating quality of Gannan yak Longissimus lumborum. Meat Sci., 112: 3-8. https://doi.org/10.1016/j.meatsci.2015.10.0 11 
Lawrie, R.A. (1958). Physiological stress in relation to dark cutting beef. J. Sci. Food, Agric., $\quad$ 9: 721-727. https://doi.org/10.1002/jsfa.2740091106

Lawrie, R. \& Ledward. D.A. (2006). The Storage and Preservation of Meat: Temperature control. 192-202. In: Ledward, D.A. (Ed.). Lawrie's Meat Science. $7^{\text {th }}$ edn. Woodhead Publ. Abington Hall, Abington Cambridge: 464pp.

Ledward, D.A.; Dickinson, R.F.; Powell, V.H., \& Shorthose, W. R. (1986). The colour and colour stability of beef longissimus dorsi and semimembranosus muscles after effective electrical stimulation. Meat Sci., 16: 245. https://doi.org/10.1016/03091740(86)90037-9

Li, Y.; Griffis, C. L.; Slavik, M.F.; Engler, P. V. \& Wolfe, R.E. (1991). Effects of current, frequency and duty cycle on killing of Salmonella in saline water using electric signals. Appl. Eng. Agric., 7: 605.

Li, Y.; Kim, J.W., Slavik, M.F.; Griffis, J.C.L.; Walker, T. \& Wang, H. (1994b). Salmonella Typhimurium attached to chicken skin reduced using electrical stimulation and inorganic salts. J. Food Sci., 59, 23. https://doi.org/10.1111/j.13652621.1994.tb06888.x

Li, Y., Siebenmorgen, T.J.; Griffis, C.L.; Wolfe, R.E.; Dake, R.L. \& Webb, J.E. (1994a). Technical notes: Tenderness and its variation of broiler breast meat harvested from electrically stimulated carcasses. Trans. ASAE, 37: 223-225.

Liu, T.; Dodds, E.; Leong, S.Y.; Eyres, G.T.; Burritt, D.J. \& Oey, I. (2017). Effect of pulsed electric fields on the structure and frying quality of "kumara" sweet potato tubers Innov. Food Sci. Emerg. Technol., 39:

197-208. https://doi.org/10.1016/j.ifset.2016.12.010

López-Campos, Ó.; Robertson, W.M.; Dugan, M.E.; Larsen, I.L.; Roberts, J.C. \& Aalhus, J.L. (2018). Effect of growth promoting hormones and high voltage electrical stimulation on meat quality of finished steers. Meat Sci., 137: 288. https://doi.org/10.1016/j.meatsci.2017.08.0 10

Lyon, B.G. \& Lyon, C.E. (1991). Research note: shear value ranges by Instron Warner-Bratzler and Allo-Kramer devices that correspond to sensory tenderness. Poult. Sci., 70: 188-191. https://doi.org/10.3382/ps.0700188

Lyon, C.E.; Davis, C.E.; Dickens, J.A.; Papa, C.M. \& Reagan, J.O. (1989). Effect of electrical stimulation on postmortem biochemical changes and texture of broiler muscle. Poultry Sci., 68: 249-257. https://doi.org/10.3382/ps.0680249

Ma, Q.; Hamid, N.; Oey, I.; Kantono, K.; Faridnia, F.; Yoo, M. \& Farouk, M. (2016). Effect of chilled and freezing pretreatments prior to pulsed electric field processing on volatile profile and sensory attributes of cooked lamb meats. Innov. Food Sci. Emerg. Technol., 37: 359-374. https://doi.org/10.1016/j.ifset.2016.04.009

Maki, A. \& Froning, G.W. (1987). Effect of post-mortem electrical stimulation on quality of turkey meat. Poult. Sci., 66: 1155-1157. https://doi.org/10.3382/ps.0661155

Mombeni, E.G.; Mombeini, M.G.; Figueiredo, L.C.; Siqueira, L.S.J. \& Dias, D.T. (2013). Effects of high voltage electrical stimulation on the rate of $\mathrm{pH}$ decline, meat quality and color stability in 
chilled beef carcasses. Asian Pac. J. Trop.

Biomed., 3(9): 716-719.

https://doi.org/10.1016/S2221-

1691(13)60144-6

Mota-Rojas, D.; Roldan-Santiago, P. \& Guerrero-Legarreta, I. (2012). Electrical Stimulation in Meat Processing. 323-329. In: Hui, Y.H. (Ed.). Handbook of Meat and Meat Processing. $2^{\text {nd }}$ edn. CRC: 959pp.

Mrigadat, B.; Smith, G.C.; Dutson, T.R.; Hall, L.C.; Hanna, M.O. \& Vanderzant, C. (1980). Bacteriology of electrically stimulated rabbit, pork, lamb and beef carcasses. J. Food Prot., 43: 686. https://doi.org/10.4315/0362-028X43.9.686

Naveena, B.M. \& Mendiratta, S.K. (2001). Tenderisation of spent hen meat using ginger extract. Br. Poult. Sci., 42: 344-349. https://doi.org/10.1080/000716601200553 13

O'Dowd, L.P.; Arimi, J.M.; Noci, F.; Cronin, D.A. \& Lyng, J.G. (2013). An assessment of the effect of pulsed electrical fields on tenderness and selected quality attributes of post rigour beef muscle. Meat Sci., 93(2):

303-309. https://doi.org/10.1016/j.meatsci.2012.09.0 10

Offer, G. (1991). Modelling of the formation of pale, soft and exudative meat: Effects of chilling regime and rate and extent of glycolysis. Meat Sci., 30: 157-184. https://doi.org/10.1016/03091740(91)90005-B

Owens, C.M. \& Sams, A.R. (1997). Muscle metabolism and meat quality of pectoralis from turkeys treated with post-mortem electrical stimulation. Poult. Sci., 76: 1047. https://doi.org/10.1093/ps/76.7.1047
Owens, C.M. \& Sams, A.R. (1998). Meat quality of broiler breast meat following post-mortem electrical stimulation at the neck. Poult. Sci., 77: 1451-1454. https://doi.org/10.1093/ps/77.9.1451

Palaniappan, S. \& Sastry, S. (1990). Effects of electricity on microorganisms: A review. J. Food Process. Preserv., 14: 393. https://doi.org/10.1111/j.17454549.1990.tb00142.x

Perlo, F.; Bonato, P.; Fabre, R.; Teira G. \& Tisocco, O. (2012). Combined effect of electrical stimulation, aging time and marination on quality of chicken breast fillet processed under commercial conditions. J. Sci. Food Agric., 92: 2183. https://doi.org/10.1002/jsfa.5606

Polidori, P. \& Vincenzetti, S. (2017). The Use of Electrical Stimulation in Meat Production. 133-153 In: McCarthy, D.B. (Ed.). Meat and Meat Processing. Nova Science Publishers, Inc.: 218pp.

Puértolas, E. \& Barba, F.J. (2016). Electrotechnologies applied to valorization of by-products from food industry: Main findings, energy and economic cost of their industrialization Food Bioprod. Process., 100 , 172-184. https://doi.org/10.1016/j.fbp.2016.06.020

Rashid, N.H.; Henrickson, R.L.; Asghar, A. \& Claypool, P.L. (1983). Biochemical and quality characteristics of ovine muscles as affected by electrical stimulation, hot boning, and mode of chilling. J. Food Sci., 48:

136-140.

https://doi.org/10.1111/j.1365-

2621.1983.tb14807.x

Riffin, T.E.; Smith, M.A.; Bush, R.D.; Collins, D. \& Hopkins. D.L. (2019). The effect of electrical stimulation and tender stretching on colour and oxidation traits of 
alpaca (Vicunga pacos) meat. Meat Sci. 156 ,

125-130.

https://doi.org/10.1016/j.meatsci.2019.05.0 26

Riley, R.R.; Savell, J.W. \& Smith, G.C. (1980). Storage characteristics of wholesale and retail cuts from electrically stimulated lamb carcasses. J. Food Sci., 45: 1101-1103. https://doi.org/10.1111/j.13652621.1980.tb07535.x

Robson, R.M.; Huff-Lonergan, E.; Parrish Jr., F.C.; Ho, C.Y.; Stromer, M.H.; Huiatt, T.W.\& Sernett, S.W. (1997). Postmortem changes in the myofibrillar and other cytoskeletal proteins in muscle. In Proc. Recip. Meat Conf. 50: 43-52.

Sams, A.R. (1995). Electrical stimulation at commercial line speeds. An update. Broiler Industry, 58(12): 20-23.

Sams, A.R. \& Dzuik, C.S. (1999). Meat quality and rigor mortis development in broiler chickens with gas-induced anoxia and postmortem electrical stimulation. Poult. Sci., 78: 1472-1476. https://doi.org/10.1093/ps/78.10.1472

Savell, J.W.; Smith, G.C.; Dutson, T.R., Carpenter, Z.L. \& Suter, D.A. (1977). Effect of electrical stimulation on palatability of beef, lamb and goat meat. J. Food Sci., 42: 702-706. https://doi.org/10.1111/j.1365-

2621.1977.tb12583.x

Slavik, M.F.; Griffis, C.L.; Li, Y. \& Engler, P.V. (1990). Effect of electrical stimulation on bacterial contamination of chicken legs. J. Food Prot., 54: 508-513. https://doi.org/10.4315/0362-028X54.7.508

Taher, M.A. (1990). Meat Science. 1st ed. Min. High. Educ. Sci. Res.: 401pp. (In Arabic).
Taylor, R.G.; Geesink, G.H.; Thompson, V.F.;Koohmaraie, M. \& Goll, D.E. (1995). Is Z-disk degrad-ation responsible for postmortem tenderization? J. Anim. Sci., 73: 1351-1367. https://doi.org/10.2527/1995.7351351x

Thompson, L.D.; Janky, D.M. \& Woodward, S.A. (1987). Tenderness and physical characteristics of broiler breast fillets harvested at various times from postmortem electrically stimulated carcasses. Poultry Sci., 66: 1158-1167. https://doi.org/10.3382/ps.0661158

Toepfl, S.; Siemer, C. \& Heinz, V. (2014). Effect of High-Intensity Electric Field Pulses on Solid Foods. 147-154. In Sun, D.W. (Ed.). Emerging Technologies for Food Processing Academic Press: 666pp. https://doi.org/10.1016/B978-0-12411479-1.00008-5

Tsong, T.Y. (1990). Reviews on electroporation of cell membranes and some related phenomena. Bioelectrochem. Bioenerg., 24(3): 271-295. https://doi.org/10.1016/03024598(90)80028-H

Walkling-Ribeiro, M.; Rodríguez-González, O.; Jayaram, S.H. \& Griffiths, M.W. (2011). Processing temperature, alcohol and carbonation levels and their impact on pulsed electric fields (PEF) mitigation of selected characteristic microorganisms in beer. Food Res. Int., 44(8): 2524-2533. https://doi.org/10.1016/j.foodres.2011.01.0 46

Warriss, P.D. (2000). Meat Science. An Introductory Text School of Veterinary Science, University of Bristol, Bristol. $2^{\text {nd }}$ edn. CABI Publishing: 223pp.

Young, L.L. \& Buhr, R.J. (2000). Effect of electrical stimulation and polyphosphate 
marination on drip from early -harvested, individually quick -frozen chicken breast fillets. Poultry Sci., 79: 925-927. https://doi.org/10.1093/ps/79.6.925

Young, L.L. \& Lyon, C.E. (1997). Effect of calcium marination on biochemical and textural properties of peri-rigor chicken breast meat. Poult. Sci., 76: 197. https://doi.org/10.1093/ps/76.1.197

Young, L.L.; Buhr, R. \& Lyon, C.E. (1999). Effect of polyphosphate treatment and electrical stimulation on postchill changes in quality of broiler breast meat. Poult. Sci., $\quad 78: \quad 267$. https://doi.org/10.1093/ps/78.2.267

Young, L.L., Cason, J.A., Smith, D.P., Lyon, C.E., Dickens, J.A. \& Walker, J.M. (2005). Effects of electrical stimulation and simulated conventional and extended chilling method on cooked chicken breast meat texture and yield. Int. J. Poult. Sci., 4(2): 60-63.

Zhang, Q., Barbosa-Canovas, G.V., \& Swanson, B.G. (1995). Engineering aspects of pulsed electric field pasteurisation. J. Food Eng., 25: 261-281. https://doi.org/10.1016/02608774(94)00030-D

Zocchi, C. \& Sams, A.S. (1999). Research notes: Tenderness of broiler breast fillets from carcasses treated with electrical stimulation and extended chilling times. Poultry Sci., 78 (3): 495-498. https://doi.org/10.1093/ps/78.3.495

\section{تأثير التحفيز الكهربائي على الخصائص النوعية لذبائح الاجاج المسنة: مراجعة شاملة} اسعد رحمان الحلفي 1 وماجد حسن الاسدي ² ونورة كريم الحميداوي² وهونك زونك3

1ققسم علوم الاغذية، كلية الزراعة، جامعة البصرة، العراق،2 قسم الثروة الحيوانية، كلية الزراعة، جامعة البصرة، العراق. 3ُ وحدة أبحاث تقييم الجودة والسلامة، المركز القومي لبحوث الدواجن بالولايات المتحدة، وزارة الزراعة الأمريكية، الولايات الهتحة الأمريكية. المستخلص: هدفت هذه المراجعة الى تلخيص الجوانب النسيجية والفيزيائية والكيميائية والميكروبية وطرق وقف التذبذب في جودة

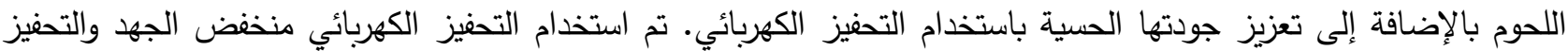

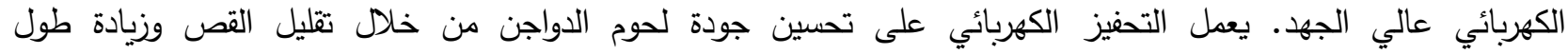
Sarcomere

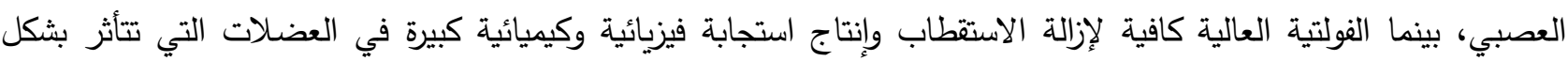

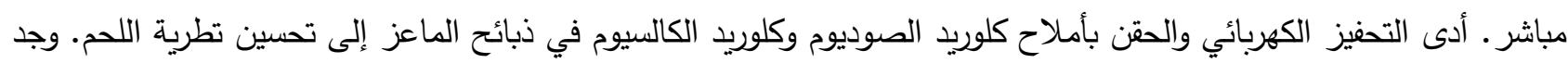

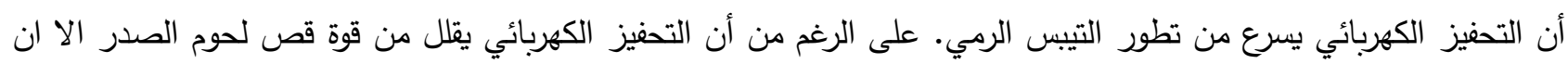

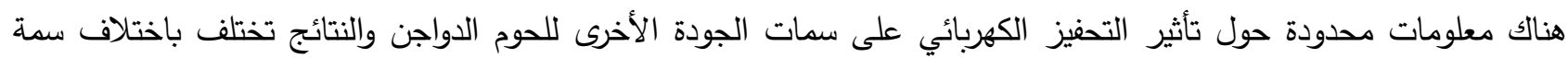

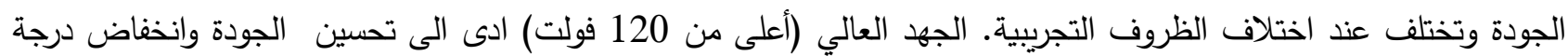
الحموضة. يتم استخدام الفولتية المنخفضة (أقل من 120 فولت) لضمان سلامة العمال وإعطاء النتائج المطلوبة عند استخدامها في التطبيقات التجارية. 